\title{
MOLECULAR AND FUNCTIONAL INTERACTIONS BETWEEN TUMOR NECROSIS FACTOR-ALPHA RECEPTORS AND THE GLUTAMATERGIC SYSTEM IN THE MOUSE HIPPOCAMPUS: IMPLICATIONS FOR SEIZURE SUSCEPTIBILITY
}

\author{
S. BALOSSO, ${ }^{a}$ T. RAVIZZA, ${ }^{a}$ M. PIERUCCI, ${ }^{b 1}$ \\ E. CALCAGNO, ${ }^{a}$ R. INVERNIZZI, ${ }^{a}$ G. DI GIOVANNI, ${ }^{b}$ \\ E. ESPOSITO ${ }^{\text {b }}$ AND A. VEZZANI ${ }^{\text {** }}$
}

a Department of Neuroscience, Laboratory of Experimental Neurology, Mario Negri Institute for Pharmacological Research, Via G. La Masa 19, 20156 Milano, Italy

${ }^{b}$ Mario Negri Institute for Pharmacological Research, Consorzio Mario Negri Sud, Santa Maria Imbaro, Chieti, Italy

\begin{abstract}
Tumor necrosis factor (TNF)-alpha is a proinflammatory cytokine acting on two distinct receptor subtypes, namely p55 and p75 receptors. TNF-alpha p55 and p75 receptor knockout mice were previously shown to display a decreased or enhanced susceptibility to seizures, respectively, suggesting intrinsic modifications in neuronal excitability. We investigated whether alterations in glutamate system function occur in these naive knockout mice with perturbed cytokine signaling that could explain their different propensity to develop seizures. Using Western blot analysis of hippocampal homogenates, we found that $\mathrm{p} 55^{-1-}$ mice have decreased levels of membrane GluR3 and NR1 glutamate receptor subunits while GluR1, GluR2, GluR6/7 and NR2A/B were unchanged as compared to wild-type mice. In p75 mice, GluR2, GluR3, GluR6/7 and NR2A/B glutamate receptor subunits were increased in the hippocampus while GluR1 and NR1 did not change. Extracellular single-cell recordings of the electrical activity of hippocampal neurons were carried out in anesthetized mice by standard electrophysiological techniques. Microiontophoretic application of glutamate increased the basal firing rate of hippocampal neurons in p $75^{-1-}$ mice versus wild-type mice, and this effect was blocked by 2-amino-5-phosphopentanoic acid and 6-nitro-7sulfamoyl-benzo(f)quinoxaline-2,3-dione denoting the involvement of $\boldsymbol{N}$-methyl-D-aspartic acid and AMPA receptors. In ${\mathrm{p} 55^{-1-}}^{-1}$ mice, hippocampal neurons responses to glutamate were similar to wild-type mice. Spontaneous glutamate release measured by in vivo hippocampal microdialysis was significantly decreased only in $\mathrm{p}^{-1-}$ mice. No changes were observed in $\mathrm{KCl}$-induced glutamate release in both receptor knockout mice strains versus wild-type mice. These findings highlight specific molecular and functional interactions between p55 and p75 receptor-mediated signaling and the glutamate system. These interactions may be relevant for controlling neuronal excitability in physiological and pathological conditions. (C) 2009 IBRO. Published by Elsevier Ltd. All rights reserved.
\end{abstract}

\footnotetext{
${ }^{1}$ Present address: Faculty of Life Sciences, University of Manchester, Manchester, UK

*Corresponding author.Tel: +39-02-39-014-410; fax+39-02-3546277. E-mail address: Vezzani@marionegri.it (A. Vezzani).

Abbreviations: AP-5, 2-amino-5-phosphopentanoic acid; NBQX, 6-nitro-7-sulfamoyl-benzo(f)quinoxaline-2,3-dione; NMDA, $N$-methyl-D-aspartic acid; TNF-alpha, tumor necrosis factor-alpha.
}

Key words: astrocytes, AMPA, cytokines, inflammation, NMDA, kainate receptors.

Cytokines are critical mediators of specific inflammatory responses and immune reactions in the CNS (Allan and Rothwell, 2001). One prototypical proinflammatory cytokine is tumor necrosis factor-alpha (TNF-alpha) that is expressed at low levels in healthy brain and it is rapidly upregulated in glia, neurons and endothelial cells in various neuropathological conditions such as ischemia, infection, trauma as well as during seizures (De Simoni et al., 2000; Sriram and O'Callaghan, 2007; Galic et al., 2008; Riazi et al., 2008). The biological actions of TNF-alpha are mediated by two receptor subtypes, namely p55 (TNFalpha R1) and p75 (TNF-alpha R2) that are coupled to distinct, although partially overlapping, intracellular signaling cascades (MacEwan, 2002; Thommesen and Laegreid, 2005). Differences in the levels and activation state of p55 and p75 receptors and related downstream effectors appear to be responsible for the divergent roles of TNF-alpha in brain (Sriram and O'Callaghan, 2007).

In physiological conditions, a constitutive release of TNF-alpha from glia has been measured (Stellwagen and Malenka, 2006; Beattie et al., 2002); p55 and p75 receptors have been described in astrocytes (Kuno et al., 2006) or neurons cultured in vitro (Pollock et al., 2002) while in rodent brain TNF-alpha receptors were predominantly observed in neurons and endothelial cells (Nadeau and Rivest, 1999; Sairanen et al., 2001; Bette et al., 2003; Balosso et al., 2005). In several disease conditions, upregulation of both $p 55$ and $p 75$ receptor subtypes has been described in glia (Munoz-Fernandez and Fresno, 1998; Gimenez et al., 2003; Shinoda et al., 2003; Sriram and O'Callaghan, 2007). The pattern of expression of TNFalpha and its receptors in physiological conditions or after brain injury suggests that this cytokine mediates both autocrine and paracrine effects.

Recent studies have shown that TNF-alpha can regulate synaptic transmission (Pickering and O'Connor, 2007; Viviani et al., 2007). In particular, TNF-alpha released by glia increases synaptic efficacy by enhancing AMPA receptors expression on neuronal surface (Beattie et al., 2002; Leonoudakis et al., 2004; Stellwagen et al., 2005), and possibly by increasing astrocytic glutamate release (Bezzi et al., 2001). Moreover, this cytokine has also been shown to affect synaptic plasticity by inhibiting LTP (Tancredi et al., 1992; Cunningham et al., 1996; Butler et al., 
2004) and by mediating synaptic scaling during activity blockade (Stellwagen and Malenka, 2006).

TNF-alpha can also contribute to pathological conditions such as neurodegeneration (Ghezzi and Mennini, 2001; Saha and Pahan, 2003; Sriram and O'Callaghan, 2007; Tansey et al., 2007) and seizure activity (Bruce et al., 1996; Probert et al., 1997; Shandra et al., 2002; Yuhas et al., 2003; Meli et al., 2004; Balosso et al., 2005; Lu et al., 2008). In this respect, we demonstrated that injection of TNF-alpha in the mouse hippocampus exerts anticonvulsant effects on kainate seizures by interacting with the neuronal p75 receptors. Accordingly, mice lacking p75 receptors are more susceptible to seizures (Balosso et al., 2005). However, in line with different roles of TNF-alpha receptor subtypes on brain function (MacEwan, 2002; Sriram and O'Callaghan, 2007), we reported that p55 receptor knockout mice have a reduced seizure susceptibility, thus suggesting the existence of an excitatory component of the TNF-alpha signaling mediated by p55 receptors (Balosso et al., 2005).

In view of the established interactions between TNFalpha and glutamatergic transmission (see above), we speculated that the changes in seizure susceptibility in TNF-alpha receptor knockout mice may involve functional modifications in the glutamatergic system.

To address this hypothesis, we investigated whether TNF-alpha p55 and p75 receptor knockout mice show intrinsic changes in the membrane levels of various subunits of ionotropic glutamate receptors as well as modifications in neuronal responses to glutamate, as assessed in the hippocampus by Western blot and electrophysiology, respectively.

In view of previous evidence that TNF-alpha affects glutamate release and its glial re-uptake (Chao et al., 1995; Bezzi et al., 2001; Zou and Crews, 2005; Takeuchi et al., 2006), we also measured extracellular glutamate levels in p55 and p75 knockout mice using brain microdialysis.

\section{EXPERIMENTAL PROCEDURES}

\section{Experimental animals}

TNF receptor knockout male adult mice (60 days old, $25 \mathrm{~g}$ ) were obtained by Taconic Farms (New York, NY, USA). Generation of these mice by using the C57BL6 strain and their detailed characterization were reported previously (Peschon et al., 1998). Agematched wild-type C57BL6 were used as controls.

Animals were housed at constant temperature $\left(23^{\circ} \mathrm{C}\right)$ and relative humidity $(60 \%)$ with a fixed 12-h light/dark cycle and free access to food and water.

Procedures involving animals and their care were conducted in accordance with the ethically approved institutional guidelines that are in compliance with national and international laws and policies (EEC Council Directive 86/609, OJ L 358, 1, Dec.12, 1987; Guide for the Care and Use of Laboratory Animals, USA; National Research Council, 1996). Experiments were carried out by minimizing the number of mice used and their suffering.

\section{Western blot}

Naive $\mathrm{p} 75^{-1-}, \mathrm{p} 55^{-1-}$ and wild type mice ( $n=5$ each group) were decapitated, the hippocampi of both hemispheres were dissected out at $4{ }^{\circ} \mathrm{C}$ and the two hippocampi of each brain were pooled. Tissue was homogenized (30 mg tissue/150 $\mu$ l homogenization buffer) as previously described (Balosso et al., 2005). An aliquot of each homogenate $(80 \mu \mathrm{l})$ was centrifuged at $45,000 \mathrm{rpm}$ at $4{ }^{\circ} \mathrm{C}$ for $1 \mathrm{~h}$ to separate cytosol and membrane fractions (Bendotti et al., 2001). Total proteins (70 $\mu \mathrm{g}$ per lane; Bio-Rad Protein Assay, Bio-Rad Laboratories, Munchen, Germany) were separated using SDS-PAGE $10 \%$ acrylamide, and each sample was run in duplicate. Proteins were transferred to Hybond nitrocellulose membranes (Whatman, Dassel, Germany) by electroblotting. For immunoblotting, we used an anti-GluR2 (1:750, Chemicon, Temecula, USA) and anti-GluR3 mouse monoclonal antibodies (1: 500, Chemicon), anti-GluR1 (1:1000, Chemicon), anti-GluR6/7 rabbit monoclonal antibodies (1:2000, Chemicon), anti-NR1 (1: 250, Chemicon) and anti-NR2A/B rabbit polyclonal antibodies (1:750, Chemicon). Immunoreactivity was visualized with enhanced chemiluminescence (ECL) using peroxidase-conjugated goat anti-mouse (1:2000; Sigma) and goat anti-rabbit (1:2000; Sigma) IgGs as secondary antibodies. Densitometric analysis of immunoblots was done to quantify the changes in protein levels (AIS image analyzer, Imaging Research, Inc., Ontario, Canada) using film exposures with maximal signals below the photographic saturation point. Optical density values in each sample were normalized using the corresponding amount of neurofilament M (NF; $1: 1000$, Chemicon) for total homogenate and $\beta$ tubulin (1:5000; Sigma, St. Louis, MO, USA) for the membrane fractions.

\section{In vivo microdialysis}

Vertical dialysis probes were prepared with a copolymer of acrylonitrile-sodium methallyl sulfonate (AN 69, Hospal, SpA, Italy; $0.31 \mathrm{~mm}$ outer diameter, with more than 44,000 Da MW cutoff), essentially as described by Robinson and Whishaw (1988). The length of the exposed membrane was $2.5 \mathrm{~mm} \mathrm{p} 75^{-1-}, \mathrm{p} 55^{-1-}$ and wild type mice $(n=7-8)$ were anesthetized with equithesin, placed on a stereotaxic frame and the dialysis probe was implanted in the ventral hippocampus. The stereotaxic coordinates were bar nose 0.0; AP - 2.6; $L+2.6 ; \mathrm{V}-3.4$ from bregma and dura surface, according to Franklin and Paxinos (1997). Twenty-four hours after surgery, the probes were perfused with artificial cerebrospinal fluid (aCSF composition in mM: $\mathrm{NaCl} 140, \mathrm{CaCl}_{2} 1.26, \mathrm{KCl} 3, \mathrm{MgCl}_{2} 1$, $\mathrm{Na}_{2} \mathrm{HPO}_{4}$ 1.2, glucose 7.2, pH 7.4 with $0.6 \mathrm{M} \mathrm{NaH}_{2} \mathrm{PO}_{4}$ ) at 1 $\mu \mathrm{L} / \mathrm{min}$ with a CMA/100 pump (CMA/Microdialysis, Stockholm, Sweden). After a washout period of $90 \mathrm{~min}$, samples of dialysate were collected every $20 \mathrm{~min}$ and stored at $4{ }^{\circ} \mathrm{C}$. A stable glutamate output was defined as three consecutive baseline samples not differing by more than $20 \%$, which was followed by 20 min perfusion with $60 \mathrm{mM} \mathrm{KCl}$ (prepared as follow in $\mathrm{mM}: \mathrm{NaCl} 87 ; \mathrm{KCl} 60$; $\mathrm{CaCl}_{2}$ 1.26; $\mathrm{MgCl}_{2} 1$, in ultrapure water, buffered at $\mathrm{pH} 7.4$ with 2 $\mathrm{mM}$ sodium phosphate buffer) to measure depolarization-induced release of glutamate (Ceglia et al., 2004).

The concentration of glutamate in dialysate samples was determined by high-performance liquid chromatography with fluorometric detection after pre-column derivatization with o-phthalaldehyde/ $\beta$-mercaptoethanol (Sigma-Aldrich, Milan, Italy) reagent according to Donzanti and Yamamoto (1988).

\section{Electrophysiological experiments}

Extracellular single unit recording. $\mathrm{p} 75^{-1-}, \mathrm{p} 55^{-1-}$ and wild type mice $(n=5-8)$ were anesthetized with chloral hydrate (400 $\mathrm{mg} / \mathrm{kg}$ i.p.) and mounted on a stereotaxic instrument (SR-6, Narishige, Japan). Supplemental doses of anesthetic were administered intraperitoneally when required. Throughout the experiment, the animal body temperature was maintained at $36-37{ }^{\circ} \mathrm{C}$ by a 
thermostatically regulated heating pad. The coordinates from bregma for placement of the recording electrode in the hippocampus were posterior $2.0-2.4 \mathrm{~mm}$, lateral $1.6-2.0 \mathrm{~mm}$ and ventral 2-2.5 mm (Franklin and Paxinos, 1997). Extracellular recordings were performed randomly in CA1, CA3 and dentate gyrus in each experimental group using multi-barrel micropipettes. Four- to sixbarrel homemade micropipettes were pulled to an optimal wide tip angle and mechanically beveled under microscopic control to a final tip diameter of 5-8 $\mu \mathrm{m}$. The central barrel, filled with $2 \mathrm{M}$ $\mathrm{NaCl}$, was used for recording (in vitro resistance 4-7 M $\mathrm{M}$ ) while one of the side barrels, filled with $2 \%$ Pontamine Sky Blue dye in $2 \mathrm{M} \mathrm{NaCl}$, was used for continuous automatic current balancing. The remaining barrels contained one of the following solutions: L-quisqualic acid (5 mM, pH 7.5), L-glutamic acid (200 mM, pH 8), 6-nitro-7-sulfamoyl-benzo(f)quinoxaline-2,3-dione (NBQX) (1 mM, $\mathrm{pH}$ 8), and 2-amino-5-phosphopentanoic acid (AP-5) $(50 \mathrm{mM}, \mathrm{pH}$ 8). All drugs were from Tocris BioScience and dosages refer to the salt weight. Unit activity was converted to an integrated histogram by a rate-averaging computer and displayed as spikes per $10 \mathrm{~s}$ intervals. After each experiment, the recording site was marked by the ejection of Pontamine Sky Blue dye from the electrode using a $-20 \mu \mathrm{A}$ current for $10 \mathrm{~min}$. Brains were removed and placed in $10 \%$ buffered formalin for 2 days before histological examination of the site of injection.

Drug administration protocol. Drugs were applied locally by microiontophoresis and the effect on the activity of hippocampal neurons was recorded. Increasing ejection currents of $-1,-2$, $-4,-8,-16$ and $-32 \mathrm{nA}$ were used to evaluate the dose-related effects of glutamate on the firing rate of recorded neurons, while a continuous ejection current of quisqualate, ranging from +1 up to -3 , was used to activate and maintain spontaneous firing since hippocampal neurons are silent under general anesthesia. A retention current of $10 \mathrm{nA}$ was used to prevent leakage of glutamate between ejection periods.

In a subsequent series of experiments, the effect of local co-administration of glutamate and D-AP5 or NBQX was evaluated using multi-barrel micropipettes. The local ejection of D-AP5 or NBQX antagonist was started $1 \mathrm{~min}$ before, and throughout the whole period of application of increasing ejection currents of glutamate. Ejection currents ranging from -2 to $-5 \mathrm{nA}$ were used for these two antagonists, while a retention current of $10 \mathrm{nA}$ was used to prevent leakage between ejection periods. A continuous ejection current of L-quisqualic acid was maintained during the entire single unit recording.

Data analysis. Data were acquired and stored on computer using an integrated software package for electrophysiology (RISI, Symbolic Logic, Dallas, TX, USA). Rate histograms were displayed as spikes per 10-s intervals. Mean firing rate calculated over the entire period of glutamate ejection $(1 \mathrm{~min})$ was used to construct current-response curves, comparing post-injection periods to basal firing rate (percentage change).

\section{Statistical analysis}

Data are represented as mean \pm standard error $(n=$ number of animals). Statistical significance was determined by using oneway ANOVA followed by Fisher's test for Western blot data or Dunnett's test for microdialysis data (for basal glutamate release). One-way ANOVA for repeated measures followed by either Fisher's PLSD or Dunnett's test was used for the statistical analysis of electrophysiological or microdialysis data (for depolarization-induced glutamate release) respectively; the genotype was considered as between the subject factor and the ejecting currents (electrophysiology) or time (microdialysis) as the within subject factor.

\section{RESULTS}

\begin{abstract}
AMPA, $\mathrm{N}$-methyl-D-aspartic acid (NMDA) and kainate receptor subunits in the hippocampus of $\mathrm{p}^{-1-}$ or p $75^{-1-}$ mice
\end{abstract}

Fig. 1 shows the levels of AMPA (GluR2, GluR3), KA (GluR6/7) and NMDA (NR1, NR2A/B) receptor subunits in the total homogenate $(A)$ and membrane $(B)$ fractions of hippocampi from $\mathrm{p} 55^{-1-}$ or $\mathrm{p} 75^{-1-}$ mice.

p55 $5^{-1-}$ : These mice showed an average $20 \%$ decrease of GluR3 and a $30 \%$ decrease of NR1 receptor subunits in total homogenate; a $40 \%$ decrease in both receptor subunits was found in the membrane fraction. No differences were observed in the GluR1 (see relative bands in Fig. 1), GluR2, GluR6/7 and NR2A/B subunits.

p $75^{-1-}$ : These mice showed an average $40 \%$ and $80 \%$ GluR2 increase in total homogenate and membrane fraction, respectively; a $40 \%$ GluR3 increase was detected in both fractions. GluR6/7 was increased by $50 \%$ and NR2A/B subunits were increased by $40 \%$ on average in both fractions compared to wild-type mice. No differences were found in GluR1 and NR1 receptor subunits.

\section{Spontaneous and depolarization-induced glutamate release}

Microdialysis was used to measure basal and depolarization-induced glutamate release since glutamate dialysate levels reflect extracellular glutamate concentrations. Fig. $2 \mathrm{~A}$ depicts the basal glutamate release in $\mathrm{p}^{2} 5^{-1-}$ and p $75^{-1-}$ mice vs. wild-type mice. Mice lacking p55 receptors showed $\sim 50 \%$ decrease $(P<0.05$ by one-way ANOVA) of spontaneous glutamate outflow compared to wild-type mice while no significant changes were found in p $75^{-\prime-}$ mice. Fig. 2B shows the effect of $60 \mathrm{mM} \mathrm{KCl}$ on dialysate levels: no significant differences in depolarization-induced glutamate release were observed in mice lacking $\mathrm{p} 55^{-I-}$ or $\mathrm{p} 75^{-1-}$ receptors.

\section{Electrophysiological experiments}

Effect of local application of glutamate. A total of 26 neurons were recorded in vivo from the hippocampus of the three experimental groups of mice $(n=5-8)$. The quisqualate-induced basal firing rate of recorded neurons for each genotype did not differ (wild-type, 7.92 $\pm 0.9(n=5)$; p55 ${ }^{-l-}, 11.61 \pm 2.9 \quad(n=8) ; \mathrm{p} 75^{-1-}, 7.40 \pm 1.4 \quad(n=11)$; $F_{2,21}=1.306, P=0.2919$ by one-way ANOVA). Fig. 3A, B shows the effect of increasing currents of glutamate on the mean firing rate of recorded neurons. Typical rate histograms show the excitatory effect of microiontophoretically applied glutamate in the three experimental groups (Fig. $3 A)$. Mean firing rate for each current was calculated over the ejection period $(1 \mathrm{~min})$ and reached a maximal increase above baseline of $302.7 \% \pm 65.0 \%$ at $-32 \mathrm{nA}$ for the $\mathrm{p}^{-5^{--}}$group, $609.1 \% \pm 128.2 \%$ at $-32 \mathrm{nA}$ for the p $75^{-/-}$group, and $233.2 \% \pm 67.7 \%$ at $-16 \mathrm{nA}$ for wild-type mice (Fig. 3B). Statistical analysis revealed an overall significant difference between genotypes $\left(F_{4,19}=3.27\right.$, $P<0.05$ by one-way ANOVA for repeated measures) and 

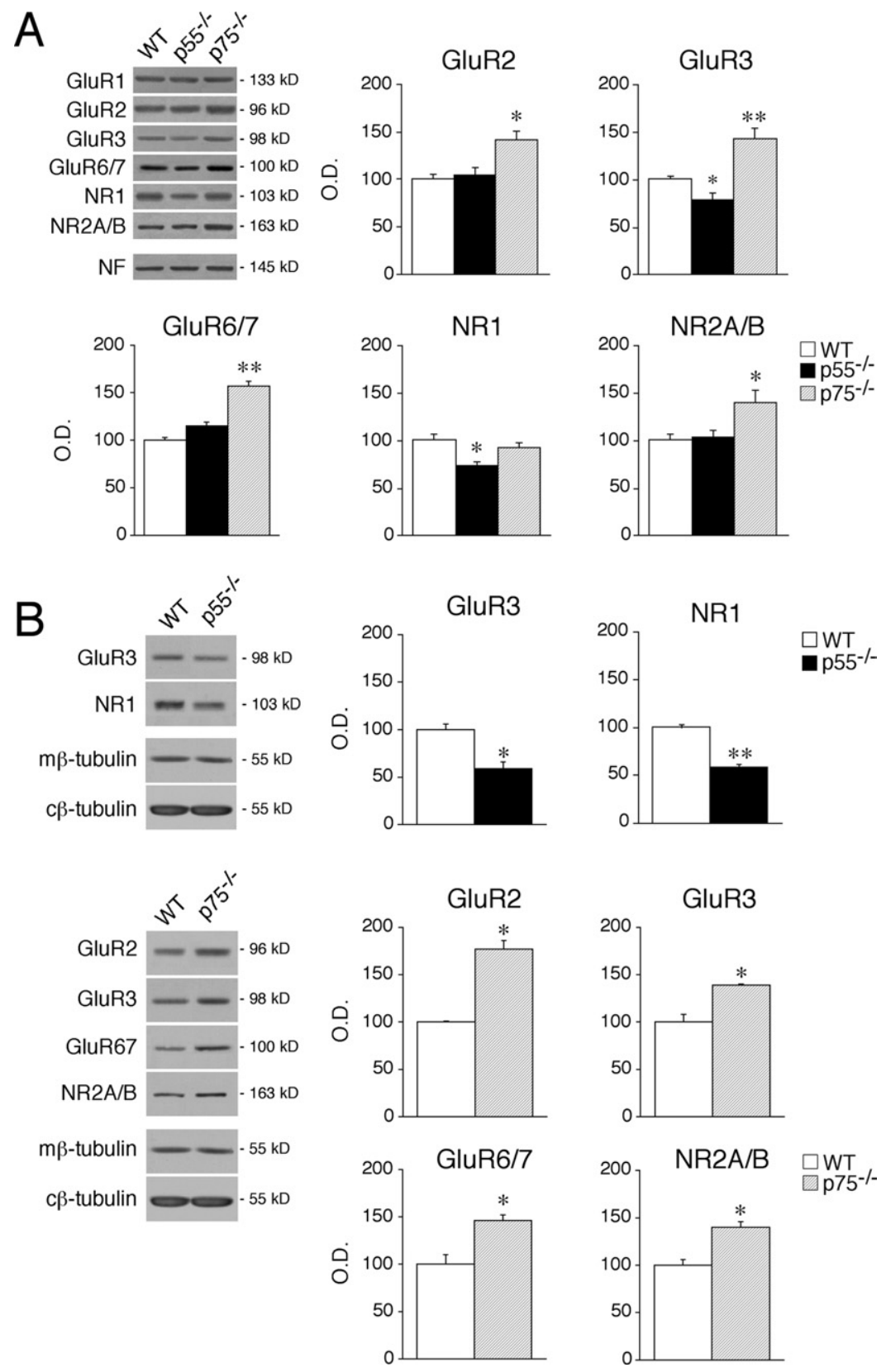

Fig. 1. AMPA, KA and NMDA receptor subunit levels in the hippocampus of $\mathrm{p} 55^{-1-}$ or $\mathrm{p} 75^{-1-}$ mice. Bargrams show densitometry analysis (mean \pm SE, $n=5$ ) of the bands corresponding to AMPA, KA and NMDA receptor subunits as assessed by Western blot analysis of hippocampal homogenates (A) or membrane (B) fractions of wild type (WT), p $55^{-1-}$ and $\mathrm{p} 75^{-1-}$ mice. The optical density (O.D.) values of the relevant bands (as depicted in the representative Western blots), are divided by the corresponding internal standard neurofilament (NF) or $\beta$-tubulin. Data are expressed as $\%$ of corresponding values in WT mice. $\mathrm{m} \beta$-Tubulin and $\mathrm{c} \beta$-tubulin represent the internal standard in the membrane $(\mathrm{m})$ or cytosol (c) fractions. ${ }^{*} P<0.05 ;{ }^{* *} P<0.01$ versus WT by one-way ANOVA followed by Fisher's test.

an overall significant effect of the increasing currents of glutamate $\left(F_{5,95}=7.73, P<0.01\right.$ by one-way ANOVA for repeated measures). Pairwise comparisons revealed a significant difference (Fisher's PLSD post hoc test) between $\mathrm{p} 75^{-1-}$ versus wild type mice at the current of -16 and $-32 \mathrm{nA}$ (Fig. 3B).

Involvement of AMPA and NMDA receptors. We evaluated if the effects elicited by glutamate on mean firing rate of recorded hippocampal neurons in the $\mathrm{p} 75^{-1-}$ mice were mediated by AMPA and/or NMDA glutamate receptors, using microiontophoretic application of the selective NMDA receptor antagonist AP-5 or the selective AMPA receptor blocker NBQX (Fig. 3B). A total number of six neurons were recorded from the hippocampus of $p 75^{-1-}$ mice exposed to glutamate with either AP-5 $(n=3)$ or NBQX $(n=3)$. AP-5 and NBQX applied individually significantly counteracted the excitation induced by microiontophoretically applied glutamate $\left(F_{4,19}=3.27, P<0.05\right.$ by 

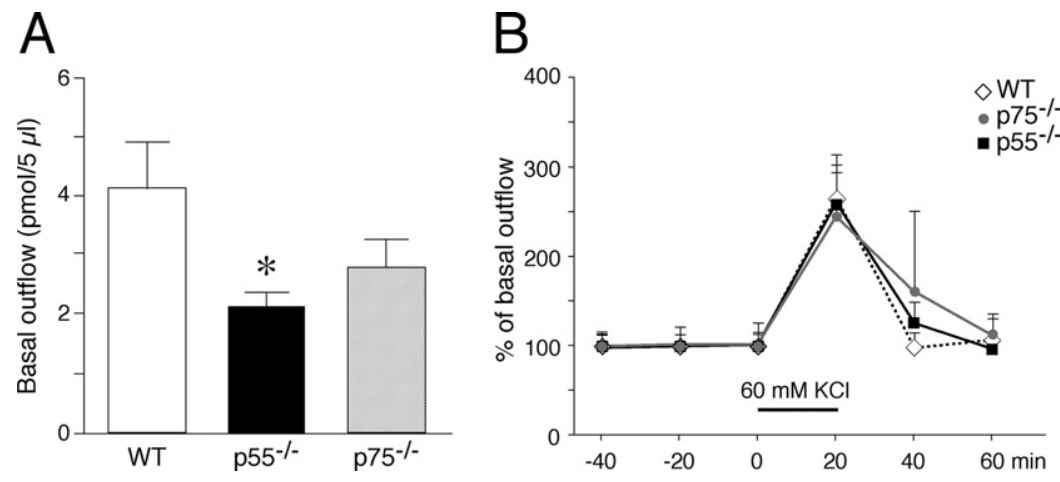

Fig. 2. Spontaneous outflow and depolarization-induced glutamate release. (A) Bargrams represent mean \pm SE $(n=7-8)$ of the basal glutamate outflow in the hippocampus of wild type (WT), p55 ${ }^{-1-}$ and $p 75^{-1-}$ mice. ${ }^{*} P<0.05$ versus WT by one-way ANOVA followed by Dunnett's test. (B) Graph represents the effect of $60 \mathrm{mM} \mathrm{KCl}$ on dialysate glutamate concentrations in the hippocampus of WT p55 ${ }^{-1-}$ and p75 $5^{-1-}$ mice, expressed as percentage of basal outflow levels.

one-way ANOVA for repeated measures). Statistical analysis also revealed a significant interaction between the applied currents and the experimental groups (wild type, $\mathrm{p} 75^{-1-}$ with/without antagonists; $F_{20,95}=1.97, P<0.05$ by one-way ANOVA for repeated measures). Pairwise comparisons showed a significant difference (Fisher's PLSD post hoc test) in the dose-response curves between $\mathrm{p} 75^{-1-}$ mice treated with glutamate alone and those with glutamate and either AP-5 or NBQX at -16 (for NBQX) and $-32 \mathrm{nA}$ ejection current (for both antagonists).

\section{DISCUSSION}

The use of TNF-alpha receptors knockout mice is a valuable tool to study the role of $\mathrm{p} 55$ and p75 receptor signaling in the physiopathological effects of this cytokine in CNS; thus, pharmacological tools that could distinguish unequivocally between these two receptors are lacking.

This study reports the main finding of significant alterations in the membrane levels of specific ionotropic glutamate receptor subunits in the hippocampus of naive mice lacking either p55 or p75 TNF-alpha receptors. The absence of TNF-alpha receptors determines modifications in different glutamate receptor subunits, namely a decrease in NR1 and GluR3 in p55 ${ }^{-1-}$ mice and an upregulation of GluR2, GluR3, GLUR6/7 and NR2AB in $p 75^{-1-}$ mice. These differential changes support previous evidence of a divergent signaling mediated by TNF-alpha receptor subtypes leading to different outcomes (Sriram and O'Callaghan, 2007).

In $\mathrm{p} 75^{-1-}$ mice, the upregulation of AMPA GluR2 and GluR3 and NMDA NR2A/B receptor subunits is associated with enhanced responses of hippocampal neurons to iontophoretically ejected glutamate, and this effect is blocked by AMPA and NMDA receptor specific antagonists. It seems therefore that the changes in GluR3 and NR2A/B receptor subunits determine an increased neuronal excitability. The upregulation of AMPA GluR2 subunit confers low $\mathrm{Ca}^{2+}$ permeability to AMPA receptors (Isaac et al., 2007), therefore this receptor conformation cannot contribute to hyperexcitability that is associated with increased neuronal $\mathrm{Ca}^{2+}$ influx, but may rather represent a compensatory homeostatic change.
Kainate GluR6/7 receptor subunits are also upregulated in these $\mathrm{p} 75^{-1-}$ mice; however, we could not investigate whether their responses to glutamate was enhanced because of the lack of selective blockers of GluR6/7-containing kainate receptors (Vincent and Mulle, 2008).

In $\mathrm{p} 55^{-1-}$ mice, we found a selective decrease in hippocampal AMPA GluR3 and NMDA NR1 protein levels. These receptor modifications were not associated with altered responses of hippocampal neurons to applied glutamate. A possible explanation is that there is a relatively small number of neurons bearing the receptor subunit changes, therefore a reduced neuronal response to glutamate may be difficult to detect by single unit electrophysiological analysis.

We also investigated whether the deletion of $p 75$ or p55 receptors was associated with modifications in extracellular glutamate levels under basal or depolarizing conditions, using in vivo microdialysis. We found that the basal extracellular glutamate level was significantly reduced in p55 $5^{-1-}$ mice as compared to wild-type controls while it did not change in $\mathrm{p} 75^{-1-}$ mice. We speculate that the decrease in basal extracellular glutamate levels in $p 55^{-1-}$ mice is due to a reduction in astrocytic glutamate release for the following reasons: (1) the basal extracellular glutamate level measured by microdialysis likely reflects glutamate release from astrocytes since it is insensitive to tetrodotoxin (TTX) and has a low dependence on $\mathrm{Ca}^{2+}$ (Del Arco et al., 2003; van der Zeyden et al., 2008); (2) TNFalpha induces the astrocytic release of glutamate acting on p55 receptors (Bezzi et al., 2001), thus supporting our finding of a reduced basal glutamate release in the absence of p55 receptors.

Moreover, the lack of changes in high $\mathrm{KCl}$-induced glutamate release in both receptor knockout mice supports the view that TNF-alpha specifically affects astrocytic, but not depolarization-dependent neuronal glutamate release (Bezzi et al., 2001; Del Arco et al., 2003).

The mechanism by which perturbation of p55 or p75 receptor signaling alters glutamate receptor levels remains to be investigated and may involve transcriptional (Furukawa and Mattson, 1998; Albensi and Mattson, 2000; MacEwen, 2002) or post-translational effects (Beattie et 

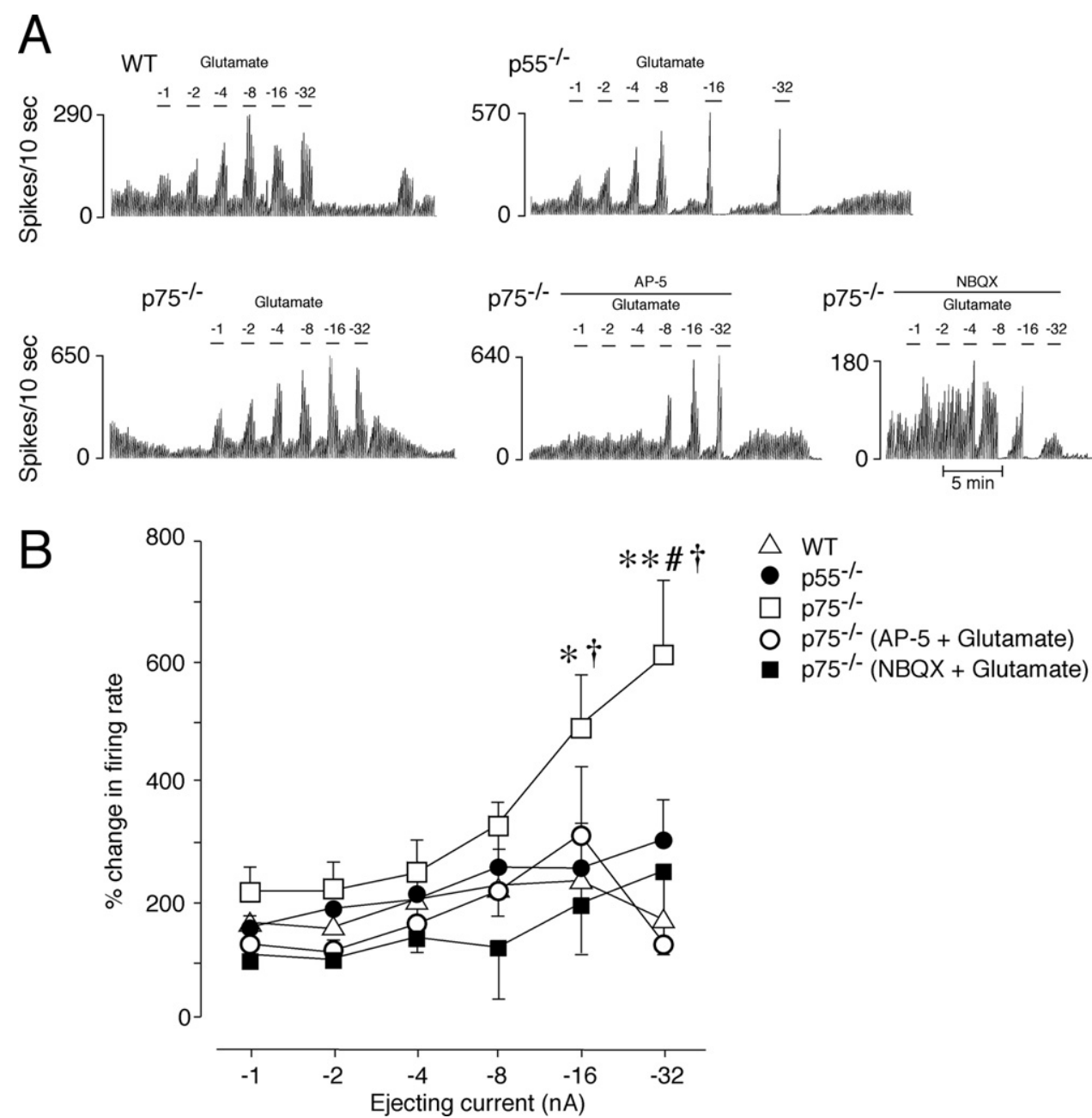

Fig. 3. Effect of local application of glutamate on the firing rate of hippocampal neurons. (A) Typical rate histograms showing the excitatory effect of microiontophoretically applied glutamate in wild-type $(n=5), \mathrm{p} 55^{-1-}(n=8), \mathrm{p} 75^{-1-}(n=5)$ mice and its blockade by AP5 and NBQX in p75 ${ }^{-1-}$ mice $(-2 \mathrm{nA} ; n=3$ in each group). Numbers above each bar indicate the ejection current of glutamate in $\mathrm{nA}$. The graph in $\mathrm{B}$ depicts current-response curves showing the mean percentage changes \pm SE elicited by glutamate in the various experimental groups, and the effect of AP5 and NBQX in p75 ${ }^{-1-}$ mice. Each point represents the mean firing rate calculated over the entire ejection period. ${ }^{*} P<0.05$; ${ }^{* *} P<0.01$ versus wild type group; \# $P<0.01$ versus AP-5+glutamate; $+P<0.05$ versus NBQX+glutamate group by one-way ANOVA for repeated measures followed by Fisher's PLSD test.

al., 2002; Ogoshi et al., 2005). This latter possibility is supported by previous evidence showing a role of phosphatidylinositol-3 kinase in TNF-alpha induced exocytosis of AMPA receptors in hippocampal pyramidal cells, an effect mediated by p55 receptors (Stellwagen et al., 2005).

The glutamate receptor changes we have measured in naive p55 and p75 knockout mice are compatible with their altered susceptibility to seizures, as reported in previous studies where these mice were intrahippocampally injected with kainic acid (Balosso et al., 2005).

In light of our present results, the increased seizure susceptibility in $\mathrm{p} 75^{-1-}$ mice (Balosso et al., 2005) could be explained by at least two non-mutually exclusive mechanisms: (1) an enhanced response of mice to kainate upon its intrahippocampal injection, due to the intrinsic upregulation of kainate GluR6/7 subunit; accordingly, the hippocampal overexpression of GluR6 predisposes to seizures (Telfeian et al., 2000) while GluR6 knockout mice are resistant to kainate seizures (Mulle et al., 1998); (2) the intrinsic upregulation of NR2A/B and GluR3 subunits may amplify the neuronal responses to glutamate that is released during kainate-induced epileptic activity. In particular, the upregulation of NR2A/B protein level in $p 75^{-1-}$ mice suggests the presence of an NMDA heteromeric receptor favoring both neuronal $\mathrm{Ca}^{2+}$ influx in response to glutamate (Viviani et al., 2003) and neuronal synchronization because of the lowest deactivation kinetics of NR2A/B containing receptors (Cull-Candy and Leszkiewicz, 2004). GluR3 receptor subunit also appears to be prominently involved in ictogenesis since rodents developing GluR3 receptor-activating antibodies develop seizures (Rogers et al., 1994; Levite and Ganor, 2008).

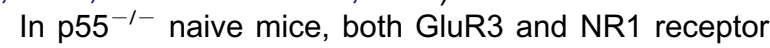
subunits are decreased but no changes in the neuronal responses to glutamate application have been observed in these mice (see above). It seems therefore unlikely that these GluR3 and NR1 modifications contribute significantly to decrease $\mathrm{p} 55^{-1-}$ mice susceptibility to kainate seizures 
(Chapman et al., 1996; Zapata et al., 1997; Balosso et al., 2005) and other mechanisms should be considered. In particular, recent evidence demonstrates a significant role of astrocytic glutamate release in determining the strength of ictal events (Fellin et al., 2006), and this release is apparently reduced in $\mathrm{p} 55^{-/-}$mice (see above).

\section{CONCLUSION}

In conclusion, our study highlights novel molecular and functional interactions between p55 and p75 receptor-mediated TNF-alpha signaling and the glutamate system in the mouse hippocampus. These findings strengthen the emerging evidence that inflammatory mediators modulate excitatory neurotransmission (Beattie et al., 2002; Viviani et al., 2003; Leonoudakis et al., 2004; Stellwagen et al., 2005; Stellwagen and Malenka, 2006; Pickering and O'Connor, 2007; Viviani et al., 2007) and suggest that TNF-alpha and glutamate interactions may play a role in pathological conditions (e.g. seizures, neurodegeneration) characterized by the activation of both systems (Ferguson et al., 2008; Vezzani and Granata, 2005).

Acknowledgments-We are grateful to our source of support EPICURE (LSH-CT-2006-037315) and Negri-Weizmann Programme.

\section{REFERENCES}

Albensi BC, Mattson MP (2000) Evidence for the involvement of TNF and NF-kappaB in hippocampal synaptic plasticity. Synapse 35 : 151-159.

Allan SM, Rothwell NJ (2001) Cytokines and acute neurodegeneration. Nat Rev Neurosci 2:734-744.

Balosso S, Ravizza T, Perego C, Peschon J, Campbell IL, De Simoni MG, Vezzani A (2005) Tumor necrosis factor-alpha inhibits seizures in mice via p75 receptors. Ann Neurol 57:804-812.

Beattie EC, Stellwagen D, Morishita W, Bresnahan JC, Ha BK, Von Zastrow M, Beattie MS, Malenka RC (2002) Control of synaptic strength by glial TNFalpha. Science 295:2282-2285.

Bendotti C, Tortarolo M, Suchak SK, Calvaresi N, Carvelli L, Bastone A, Rizzi M, Rattray M, Mennini T (2001) Transgenic SOD1 G93A mice develop reduced GLT-1 in spinal cord without alterations in cerebrospinal fluid glutamate levels. J Neurochem 79:737-746.

Bette M, Kaut O, Schafer MK, Weihe E (2003) Constitutive expression of p55TNFR mRNA and mitogen-specific up-regulation of TNF alpha and p75TNFR mRNA in mouse brain. J Comp Neurol 465: 417-430.

Bezzi P, Domercq M, Brambilla L, Galli R, Schols D, De Clercq E, Vescovi A, Bagetta G, Kollias G, Meldolesi J, Volterra A (2001) CXCR4-activated astrocyte glutamate release via TNFalpha: amplification by microglia triggers neurotoxicity. Nat Neurosci 4 : 702-710.

Bruce AJ, Boling W, Kindy MS, Peschon J, Kraemer PJ, Carpenter MK, Holtsberg FW, Mattson MP (1996) Altered neuronal and microglial responses to excitotoxic and ischemic brain injury in mice lacking TNF receptors. Nat Med 2:788-794.

Butler MP, O'Connor JJ, Moynagh PN (2004) Dissection of tumornecrosis factor-alpha inhibition of long-term potentiation (LTP) reveals a p38 mitogen-activated protein kinase-dependent mechanism which maps to early-but not late-phase LTP. Neuroscience 124:319-326.

Ceglia I, Carli M, Baviera M, Renoldi G, Calcagno E, Invernizzi RW (2004) The 5-HT receptor antagonist M100907 prevents extracel- lular glutamate rising in response to NMDA receptor blockade in the mPFC. J Neurochem 91:189-199.

Chao CC, Hu S, Ehrlich L, Peterson PK (1995) Interleukin-1 and tumor necrosis factor-alpha synergistically mediate neurotoxicity: involvement of nitric oxide and of $\mathrm{N}$-methyl-D-aspartate receptors. Brain Behav Immun 9:335-365.

Chapman AG, Woodburn VL, Woodruff GN, Meldrum BS (1996) Anticonvulsant effect of reduced NMDA receptor expression in audiogenic DBA/2 mice. Epilepsy Res 26:25-35.

Cull-Candy SG, Leszkiewicz DN (2004) Role of distinct NMDA receptor subtypes at central synapses. Sci STKE 255:re16.

Cunningham AJ, Murray CA, O'Neill LA, Lynch MA, O'Connor JJ (1996) Interleukin-1 beta (IL-1 beta) and tumour necrosis factor (TNF) inhibit long-term potentiation in the rat dentate gyrus in vitro. Neurosci Lett 203:17-20.

Del Arco A, Segovia G, Fuxe K, Mora F (2003) Changes in dialysate concentrations of glutamate and GABA in the brain: an index of volume transmission mediated actions? J Neurochem 85:23-33.

De Simoni MG, Perego C, Ravizza T, Moneta D, Conti M, Marchesi F, De Luigi A, Garattini S, Vezzani A (2000) Inflammatory cytokines and related genes are induced in the rat hippocampus by limbic status epilepticus. Eur J Neurosci 12:2623-2633.

Donzanti BA, Yamamoto BK (1988) An improved and rapid HPLC-EC method for the isocratic separation of amino acid neurotransmitters from brain tissue and microdialysis perfusates. Life Sci 43:913922.

Fellin T, Gomez-Gonzalo M, Gobbo S, Carmignoto G, Haydon PG (2006) Astrocytic glutamate is not necessary for the generation of epileptiform neuronal activity in hippocampal slices. J Neurol Sci 26:9312-9322.

Ferguson AR, Christensen RN, Gensel JC, Miller BA, Sun F, Beattie EC, Bresnahan JC, Beattie MS (2008) Cell death after spinal cord injury is exacerbated by rapid TNF alpha-induced trafficking of GluR2-lacking AMPARs to the plasma membrane. J Neurol Sci 28:11391-11400.

Franklin KBJ, Paxinos G (1997) The mouse brain in stereotaxic coordinates. San Diego: Academic Press.

Furukawa K, Mattson MP (1998) The transcription factor NF-kappaB mediates increases in calcium currents and decreases in NMDAand AMPA/kainate-induced currents induced by tumor necrosis factor-alpha in hippocampal neurons. J Neurochem 70:18761886.

Galic MA, Riazi K, Heida JG, Mouihate A, Fournier NM, Spencer SJ, Kalynchuk LE, Teskey GC, Pittman QJ (2008) Postnatal inflammation increases seizure susceptibility in adult rats. J Neurol Sci 28:6904-6913.

Ghezzi P, Mennini T (2001) Tumor necrosis factor and motoneuronal degeneration: an open problem. Neuroimmunomodulation 9:178182.

Gimenez F, Barraud de Lagerie S, Fernandez C, Pino P, Mazier D (2003) Tumor necrosis factor alpha in the pathogenesis of cerebral malaria. Cell Mol Life Sci 60:1623-1635.

Isaac JT, Ashby M, McBain CJ (2007) The role of the GluR2 subunit in AMPA receptor function and synaptic plasticity. Neuron 54:859871.

Kuno R, Yoshida Y, Nitta A, Nabeshima T, Wang J, Sonobe Y, Kawanokuchi J, Takeuchi H, Mizuno T, Suzumura A (2006) The role of TNF-alpha and its receptors in the production of NGF and GDNF by astrocytes. Brain Res 1116:12-18.

Leonoudakis D, Braithwaite SP, Beattie MS, Beattie EC (2004) TNFalpha-induced AMPA-receptor trafficking in CNS neurons; relevance to excitotoxicity? Neuron Glia Biol 1:263-273.

Levite M, Ganor Y (2008) Autoantibodies to glutamate receptors can damage the brain in epilepsy, systemic lupus erythematosus and encephalitis. Expert Rev Neurother 8:1141-1160.

Lu MO, Zhang XM, Mix E, Quezada HC, Jin T, Zhu J, Adem A (2008) TNF-alpha receptor 1 deficiency enhances kainic acid-induced hippocampal injury in mice. J Neurol Sci Res 86:1608-1614. 
MacEwan DJ (2002) TNF ligands and receptors-a matter of life and death. Br J Pharmacol 135:855-875.

Meli DN, Loeffler JM, Baumann P, Neumann U, Buhl T, Leppert D, Leib SL (2004) In pneumococcal meningitis a novel water-soluble inhibitor of matrix metalloproteinases and TNF-alpha converting enzyme attenuates seizures and injury of the cerebral cortex. J Neuroimmunol 151:6-11.

Mulle C, Sailer A, Perez-Otano I, Dickinson-Anson H, Castillo PE, Bureau I, Maron C, Gage FH, Mann JR, Bettler B, Heinemann SF (1998) Altered synaptic physiology and reduced susceptibility to kainate-induced seizures in GluR6-deficient mice. Nature 392: 601-605.

Munoz-Fernandez MA, Fresno M (1998) The role of tumour necrosis factor, interleukin 6 , interferon-gamma and inducible nitric oxide synthase in the development and pathology of the nervous system. Prog Neurobiol 56:307-340.

Nadeau S, Rivest S (1999) Effects of circulating tumor necrosis factor on the neuronal activity and expression of the genes encoding the tumor necrosis factor receptors (p55 and p75) in the rat brain: a view from the blood-brain barrier. Neuroscience 93:1449-1464.

Ogoshi F, Yin HZ, Kuppumbatti Y, Song B, Amindari S, Weiss JH (2005) Tumor necrosis-factor-alpha (TNF-alpha) induces rapid insertion of $\mathrm{Ca}^{2+}$-permaeble alpha-amino-3-hydroxil-5-methyl-4isoxazole-propionate (AMPA)/kainate $(\mathrm{Ca}-\mathrm{A} / \mathrm{K})$ channels in a subset of hippocampal pyramidal neurons. Exp Neurol 193:384-393.

Peschon JJ, Torrance DS, Stocking KL, Glaccum MB, Otten C, Willis CR, Charrier K, Morrissey PJ, Ware CB, Mohler KM (1998) TNF receptor-deficient mice reveal divergent roles for p55 and p75 in several models of inflammation. J Immunol 160:943-952.

Pickering M, O'Connor JJ (2007) Pro-inflammatory cytokines and their effects in the dentate gyrus. Prog Brain Res 163:339-354.

Pollock J, McFarlane SM, Connell MC, Zehavi U, Vandenabeele P, MacEwan DJ, Scott RH (2002) TNF-alpha receptors simultaneously activate $\mathrm{Ca}^{2+}$ mobilisation and stress kinases in cultured sensory neurones. Neuropharmacology 42:93-106.

Probert L, Akassoglou K, Kassiotis G, Pasparakis M, Alexopoulou L, Kollias G (1997) TNF-alpha transgenic and knockout models of CNS inflammation and degeneration. J Neuroimmunol 72:137141.

Riazi K, Galic MA, Kuzmiski JB, Ho W, Sharkey KA, Pittman QJ (2008) Microglial activation and TNFalpha production mediate altered CNS excitability following peripheral inflammation. Proc Natl Acad Sci U S A 105:17151-17156.

Robinson TE, Whishaw IQ (1988) Normalization of extracellular dopamine in striatum following recovery from a partial unilateral 6-OHDA lesion of the substantia nigra: a microdialysis study in freely moving rats. Brain Res 450:209-224.

Rogers SW, Andrews PI, Gahring LC, Whisenand T, Cauley K, Crain B, Hughes TE, Heinemann SF, McNamara JO (1994) Autoantibodies to glutamate receptor GluR3 in Rasmussen's encephalitis. Science 265:648-651.

Saha RN, Pahan K (2003) Tumor necrosis factor-alpha at the crossroads of neuronal life and death during HIV-associated dementia. J Neurochem 86:1057-1071.

Sairanen T, Carpen O, Karjalainen-Lindsberg ML, Paetau A, Turpeinen U, Kaste M, Lindsberg PJ (2001) Evolution of cerebral tumor necrosis factor-alpha production during human ischemic stroke. Stroke 32:1750-1758.
Shandra AA, Godlevsky LS, Vastyanov RS, Oleinik AA, Konovalenko VL, Rapoport EN, Korobka NN (2002) The role of TNF-alpha in amygdala kindled rats. Neurosci Res 42:147-153.

Shinoda S, Skradski SL, Araki T, Schindler CK, Meller R, Lan JQ, Taki W, Simon RP, Henshall DC (2003) Formation of a tumour necrosis factor receptor 1 molecular scaffolding complex and activation of apoptosis signal-regulating kinase 1 during seizure-induced neuronal death. Eur J Neurosci 17:2065-2076.

Sriram K, O'Callaghan JP (2007) Divergent roles for tumor necrosis factor-alpha in the brain. J Neuroimmune Pharmacol 2:140-153.

Stellwagen D, Beattie EC, Seo JY, Malenka RC (2005) Differential regulation of AMPA receptor and GABA receptor trafficking by tumor necrosis factor-alpha. J Neurol Sci 25:3219-3228.

Stellwagen D, Malenka RC (2006) Synaptic scaling mediated by glial TNF-alpha. Nature 440:1054-1059.

Takeuchi H, Jin S, Wang J, Zhang G, Kawanokuchi J, Kuno R, Sonobe Y, Mizuno T, Suzumura A (2006) Tumor necrosis factor-alpha induces neurotoxicity via glutamate release from hemichannels of activated microglia in an autocrine manner. J Biol Chem 281: 21362-21368.

Tancredi V, D’Arcangelo G, Grassi F, Tarroni P, Palmieri G, Santoni A, Eusebi $F$ (1992) Tumor necrosis factor alters synaptic transmission in rat hippocampal slices. Neurosci Lett 146:176-178.

Tansey MG, McCoy MK, Frank-Cannon TC (2007) Neuroinflammatory mechanisms in Parkinson's disease: potential environmental triggers, pathways, and targets for early therapeutic intervention. Exp Neurol 1:1-25.

Telfeian AE, Federoff HJ, Leone P, During MJ, Williamson A (2000) Overexpression of GluR6 in rat hippocampus produces seizures and spontaneous nonsynaptic bursting in vitro. Neurobiol Dis 7:362-374.

Thommesen L, Laegreid A (2005) Distinct differences between TNF receptor 1- and TNF receptor 2-mediated activation of NFkappaB. $\mathrm{J}$ Biochem Mol Biol 38:281-289.

van der Zeyden M, Oldenziel WH, Rea K, Cremers TI, Westerink BH (2008) Microdialysis of GABA and glutamate: analysis, interpretation and comparison with microsensors. Pharmacol Biochem Behav 90:135-147.

Vezzani A, Granata T (2005) Brain inflammation in epilepsy: experimental and clinical evidence. Epilepsia 46:1724-1743.

Vincent $P$, Mulle C (2008) Kainate receptors in epilepsy and excitotoxicity. Neuroscience 158:309-323.

Viviani B, Bartesaghi S, Gardoni F, Vezzani A, Behrens MM, Bartfai T, Binaglia M, Corsini E, Di LM, Galli CL, Marinovich M (2003) Interleukin-1beta enhances NMDA receptor-mediated intracellular calcium increase through activation of the Src family of kinases. J Neurol Sci 23:8692-8700.

Viviani B, Gardoni F, Marinovich M (2007) Cytokines and neuronal ion channels in health and disease. Int Rev Neurobiol 82:247-263.

Yuhas Y, Weizman A, Ashkenazi S (2003) Bidirectional concentrationdependent effects of tumor necrosis factor alpha in Shigella dysenteriae-related seizures. Infect Immun 71:2288-2291.

Zapata A, Capdevila JL, Tarrason G, Adan J, Martinez JM, Piulats J, Trullas R (1997) Effects of NMDA-R1 antisense oligodeoxynucleotide administration: behavioral and radioligand binding studies. Brain Res 745:114-120.

Zou JY, Crews FT (2005) TNF alpha potentiates glutamate neurotoxicity by inhibiting glutamate uptake in organotypic brain slice cultures: neuroprotection by NF kappa B inhibition. Brain Res 1034: $11-24$. 